\title{
The Causal Link between Spending and Revenue: The Lao PDR
}

\author{
Phouthanouphet Saysombath $^{1} \&$ Phouphet Kyophilavong $^{2}$ \\ ${ }^{1}$ Graduate Office, National University of Laos, Vientiane Capital, Lao PDR \\ ${ }^{2}$ Faculty of Economics and Business Management, National University of Laos, Vientiane Capital, Lao PDR \\ Correspondence: Phouthanouphet Saysombath, Graduate Office, National University of Laos, Vientiane Capital, \\ Lao PDR. Tel: 856-20-9991-2888. E-mail: phouthanouphet@yahoo.com
}

Received: June 29, 2013

Accepted: August 19, 2013 Online Published: September 26, 2013

doi:10.5539/ijef.v5n10p111

URL: http://dx.doi.org/10.5539/ijef.v5n10p111

\begin{abstract}
With this paper, we investigate the link between spending and revenue for the Lao PDR during the period of 1980 to 2010. We apply an approach that uses cointegration and an autoregressive distributed lag (ARDL) combined with a Granger causality within a vector error correction framework (VECM). The results disclose that a long-run causality exists between government spending and revenue. This causality is unidirectional from spending to revenue, which supports the spend-and-tax hypothesis. Our results can help policy makers determine whether government spending is primarily the outcome of an increase in tax revenue necessary to finance the spending.
\end{abstract}

Keywords: government revenue, spending, ARDL bounds testing, granger causality, Lao PDR

\section{Introduction}

Researchers and policy makers have been interested in public finance for many years. The debate on the link between spending and revenue in government continues to this day. The many empirical studies on both developed and developing countries examine this link. These empirical studies have mixed results that vary from country to country.

The Lao PDR has faced persistent budget deficits over time. These budget deficits accounted for 5\% of its GDP in 2010 (World Bank, 2012). The government deficit is financed mostly through government revenue and international development assistance. In addition, the government revenues are largely dependent on natural resources. The fiscal revenues from this sector went from 3\% in 2001 to around $18 \%$ of total revenues in 2008 . The contribution from the mining and energy sectors to the GDP in particular went from approximately $2.5 \%$ before 1997 to $12 \%$ in 2008 . Thus, natural resources contributed more than one-fifth of the total economic growth over that period (World Bank, 2012). Therefore, finding the link between government spending and revenue is important for the Lao PDR. However, on the empirical side, the literature that exists is very limited on this issue for the Lao PDR.

This paper's objective is to investigate the link between spending and revenue and its implication for managing a budget deficit. In order to examine this long-run link, we apply the ARDL approach combined with the Granger causality in a VECM framework.

There are two contributions of this paper. First, this study is a pioneering effort by investigating the link between government spending and revenue in the Lao PDR. Second, we use the ARDL approach to cointegration that Pesaran, Shin and Smith (2001) develop in their paper.

This paper is organized as follows: In Section 2, we discuss the literature and its findings. In Section 3, we provide the modeling, empirical strategy, and data collection. Section 4 provides the results and the last section is the conclusion.

\section{Literature Review}

The research has not empirically resolved what direction the link between spending and revenue takes and hence how it affects budget deficits. Theoretically, four alternative hypotheses exist that describe this link.

The first and second hypotheses cover tax-and-spend and spend-and-tax. The third hypothesis is fiscal synchronization. Finally, the fourth hypothesis is fiscal neutrality, also known as institutional separation. For 40 
years, the outcomes of these studies have varied with sometimes conflicting results. These results seem to focus on the causality's direction.

Friedman (1978) originally proposed the tax-and-spend school. This school of thought claims that there is a positive link between government spending and revenue. Moalusi (2004) and Keho (2010) demonstrate that decreasing taxes is an appropriate policy for a budget deficit. In contrast, Buchanan \& Wagner (1978) propose that increasing tax revenues is the solution. They argue that a decline in taxes is perceived by the public as falling costs for government programs. Chang, Liu and Caudill (2002) study this link in ten industrialized countries that include the newly industrialized Asian economies of Taiwan, South Korea, and Thailand. They find causality from government revenue to spending in the three Asian countries along with the United Kingdom and the United States. Wolde - Rufael (2008) find unidirectional causality running from revenue to expenditure for Ethiopia, Ghana, Kenya, Nigeria, Mali and Zambia. Dalena \& Magazzino (2012) find the unidirectional Granger causality running from public revenues to public spending in Italy.

Peacock \& Wiseman (1961 \& 1979) propose the spend-and-tax school. This school argues that spending causes revenue. Barro (1979) further finds that short-lived increases in government spending (arising from natural crises) become long lasting and result in tax increases to finance the excessive spending. Anderson, Wallace and Warner (1986) examine this relation in the United States. This study finds that the direction of the causal association leads from spending to revenue. Furstenberg, Green and Jeong, Jin-H (1986) claim that government spending propels revenues in the United States. Wolde - Rufael (2008) find unidirectional causality running from expenditure to revenue for Burkina Faso. Gounder \& Narayan (2007) find government expenditure Granger causes government revenue in Fiji.

The third hypothesis is called fiscal synchronization (Musgrave, 1966; Meltzer \& Richard, 1981). This hypothesis states that there is a bidirectional causality between spending and revenue through simultaneous decision making. Li (2001) finds that bidirectional causality exists in China. Konukcu-Önal \& Tosun (2008) find bidirectional causality found for the Kyrgyz Republic and Kazakhstan. Wolde - Rufael (2008) find bi-directional causality running between expenditure and revenue for Mauritius, Swaziland and Zimbabwe which supports the fiscal synchronization hypothesis.

The fourth hypothesis, which is proposed by Baghestani \& McNown (1994), is called the fiscal neutrality school. This hypothesis states that revenue and spending are not linked to each other. Jalil (2012) find no causality is found between its revenue and its expenditure in Penang. Narayan \& Narayan (2006) find neutrality relationship in Peru, South Africa, Guatemala, Uruguay and Ecuador.

The literature illustrates that the direction of the link between spending and revenue is mixed due to the difference in data sets, econometric methods, and country-level characteristics (Payne, 2003). Although this link is critical for the evaluation of fiscal imbalances, the empirical research on the link does not exist for the Lao PDR.

\section{Methodology and Data Collection}

The link between government spending and revenue is specified as follows:

$$
\ln G E_{t}=\alpha_{1}+\alpha_{2} \ln G R_{t}+\mu_{\mathrm{t}}
$$

And

$$
\ln G R_{t}=\beta_{1}+\beta_{2} \ln G R_{t}+\mu_{t}
$$

where the GE and the GR denote government spending and revenue respectively. The $\mu$ is an error term. We expect that $\alpha_{2}$ and $\beta_{2}>0$. The definition of government spending is its ratio to GDP. The government revenue is defined as the ratio of revenue to GDP.

We examine the long-run link between government spending and revenue by using an ARDL testing approach to cointegration. Pesaran \& Pesaran (1997), Pesaran \& Shin (1999) and Pesaran et al. (2001) sequentially develop this approach and find this method to be more efficient than other techniques. There are several comparative advantages to the ARDL that make it more useful than others. First, the ARDL is flexible in relation to a small sample size such as ours. The method allows for the integration of the variables regardless of their order, and whether they are stationary at $\mathrm{I}(1)$ or $\mathrm{I}(0)$. Second, the ARDL determines a dynamic unrestricted error model (UECM) through a linear transformation. The UECM integrates the short-run dynamics with the long-run equilibrium without losing any information over time. The formula for the ARDL approach to cointegration is:

$$
\Delta \ln G E_{t}=c_{1}+\pi_{l} \ln G E_{t-1}+\pi_{2} \ln G R_{t-1}+\sum_{i=1}^{p} \theta_{i} \Delta \ln G E_{t-i}+\sum_{i=1}^{p} \phi_{i} \Delta \ln G R_{t-i}+u_{l t}
$$

And 


$$
\Delta \ln G R_{t}=c_{2}+\pi_{1} \ln G R_{t-1}+\pi_{2} \ln G E_{t-1}+\sum_{i=1}^{p} \theta_{i} \Delta \ln G R_{t-i}+\sum_{i=1}^{p} \phi_{i} \Delta \ln G E_{t-i}+u_{2 t}
$$

The $\Delta$ is the operator for the first difference logarithm. The constants are $c_{1}$ and $c_{2}$, the coefficients on the trend term are $\delta_{1}$ and $\delta_{2}$, and the coefficients for the lagged-level dependent and independent variables are the $\pi_{1}$ and $\pi_{2}$ respectively. The $\theta_{\mathrm{i}}$ and $\phi_{\mathrm{i}}$ represent the lagged dependent and independent variables respectively. The $\mathrm{u}_{1 \mathrm{t}}$ and $\mathrm{u}_{2 \mathrm{t}}$ are error terms. And the $\mathrm{P}$ represents the maximum lag length that is decided by the user.

There are two procedures for the ARDL. The first procedure uses a F-test to determine the joint significance of the lagged-level variables. The null hypothesis denotes the non-existence of a long-term relation as $\left(\ln G E_{t} / \ln G R_{t}\right)$ with (Ho: $\left.\pi_{1}=\pi_{2}=0\right)$ versus $\left(\mathrm{H}_{\mathrm{a}}: \pi_{1} \neq \pi_{2} \neq 0\right.$ ). Pesaran et al. (2001) find lower and upper critical bounds in the F-test. If the F-statistic is greater than the upper critical bound, then the lack of cointegration among the variables in the null hypothesis is rejected. If the F-statistic is less than the lower bound, then the null hypothesis is accepted. ${ }^{1}$ The next step is to estimate the long-run and short-run equations by using the ECM. To ensure the convergence to the long-run equilibrium, the sign for the coefficient of the lagged error correction term $\left(\mathrm{ECM}_{\mathrm{t}-1}\right)$ must be negative and statistically significant. Further, we conduct the diagnostic tests (Pesaran \& Pesaran, 1997).

After the cointegration of the variables is established for the long-run relation, the long-run and the short-run causality can be examined. The Granger causality from the VECM framework is used to determine the direction of the causality between the variables. The VECM is developed as follows:

$$
(1-L)\left[\begin{array}{l}
\ln G E_{t} \\
\ln G R_{t}
\end{array}\right]=\left[\begin{array}{l}
\phi_{1} \\
\phi_{2}
\end{array}\right]+\sum_{i=1}^{p}(1-L)\left[\begin{array}{ll}
a_{11 i} & a_{12 i} \\
b_{21 i} & b_{22 i}
\end{array}\right]+\left[\begin{array}{l}
\xi_{1} \\
\xi_{2}
\end{array}\right] \times\left[\begin{array}{l}
\ln G E_{t-1} \\
\ln G R_{t-1}
\end{array}\right] \times\left[E C M_{t-1}\right]+\left[\begin{array}{l}
\mu_{1 t} \\
\mu_{2 t}
\end{array}\right]
$$

where the difference operator is $(1-L)$, and the $E C M_{t-1}$ is generated from the long-term association. The significance of the coefficient for the $E C M_{t-1}$ uses the t-test statistic to indicate the causality over the long run. To test the direction of the causality between the variables in the short run, we use the significance of the F statistic.

We use annual time series data that covers the period of 1980 to 2010 in which those data are available. All of the data were collected from the World Development Indicators.

\section{Results}

We apply the ARDL to find the long-run link between government spending and revenue in the Lao PDR. To ensure that the variables are not stationary at I(2),we use the augmented Dickey-Fuller (ADF) (Dickey \& Fuller, 1979 and 1981) and PP tests (Phillips \& Perron, 1988). The unit root test shows that the RE and the GR are stationary in their different forms with the intercept and the trend. This finding implies that our variables have an order of integration that is $\mathrm{I}(1)$.

\begin{tabular}{|c|c|c|c|c|c|c|c|c|}
\hline & \multicolumn{4}{|c|}{ ADF test } & \multicolumn{4}{|c|}{ PP test } \\
\hline & \multicolumn{2}{|c|}{ Level } & \multicolumn{2}{|c|}{ Difference } & \multicolumn{2}{|c|}{ Level } & \multicolumn{2}{|c|}{ Difference } \\
\hline & Intercept & With trend & Intercept & With trend & Intercept & With trend & Intercept & With trend \\
\hline $\operatorname{lnGR}$ & $\begin{array}{c}-2.2540 \\
\text { (1) }\end{array}$ & $\begin{array}{c}-2.8630 \\
(1)\end{array}$ & $\begin{array}{c}3.9850^{*} \\
(0)\end{array}$ & $\begin{array}{c}-4.5459^{*} \\
(0)\end{array}$ & $\begin{array}{c}-2.3887 \\
\text { (3) }\end{array}$ & $\begin{array}{c}-1.9278 \\
(2)\end{array}$ & $\begin{array}{c}-4.0125^{*} \\
\text { (1) }\end{array}$ & $\begin{array}{c}-4.5063^{*} \\
(4)\end{array}$ \\
\hline $\operatorname{lnGE}$ & $\begin{array}{c}-2.1790 \\
(0)\end{array}$ & $\begin{array}{c}-1.5590 \\
(0)\end{array}$ & $\begin{array}{c}5.2846^{*} \\
(0)\end{array}$ & $\begin{array}{c}-6.2137^{*} \\
(0)\end{array}$ & $\begin{array}{c}-2.5247 \\
(2)\end{array}$ & $\begin{array}{c}-1.4723 \\
\text { (3) }\end{array}$ & $\begin{array}{c}-5.3107^{*} \\
\text { (3) }\end{array}$ & $\begin{array}{c}-6.1811^{*} \\
(1)\end{array}$ \\
\hline
\end{tabular}

Table 1. The unit root test

Note: * indicates the significance at the $1 \%$ level. ( ) denotes the length of the lag in the ADF test and the bandwidth in the PP test.

We select the optimal lag length by using the Schwarz Bayesian Criterion (SBC). The result indicates that one is the optimal lag order. ${ }^{2}$ To account for a relatively small sample size, we produce new critical values (CVs) for the F-test computed by stochastic simulations with 20,000 replications. Table 2 reports the computed F-statistic for cointegration.

When the dependent variable is $\operatorname{lnGE} t$, then the calculated F-statistic $\left(F\left(\operatorname{lnGE}_{t} / \operatorname{lnGR}_{t}\right)=5.93\right)$ is higher than the upper critical bound at the $10 \%$ significance level. Further, when the dependent variable is $\operatorname{lnGR}_{t}$, then the calculated F-statistic is greater than the upper critical bound at the 5\% significance level. These results suggest that cointegration exists between government spending and revenue in Laos. 
Table 2. Cointegration results of the ARDL test

\begin{tabular}{ccc}
\hline Variable & $\operatorname{lnGR}_{\mathrm{t}}$ & $\operatorname{lnGE}_{\mathrm{t}}$ \\
\hline F-statistics & $7.2300^{*}$ & $5.9359^{* *}$ \\
Cittical values & $5 \%$ level & $10 \%$ level \\
Lower bounds & 5.5107 & 4.3679 \\
Upper bounds & 6.3780 & 5.1615 \\
Diagnostic tests & & \\
$\mathrm{R}^{2}$ & 0.9959 & 0.9920 \\
Adj- $\mathrm{R}^{2}$ & 0.9956 & 0.9911 \\
Durbin-Watson & 1.5030 & 1.7645 \\
\hline
\end{tabular}

Note: The $*$ and $* *$ show the significance at the $5 \%$ and $10 \%$ levels respectively.

Table 3 shows the long-run and short-run analysis. The empirical evidence shows that government spending is statistically significant in determining the government revenue in both the long run and the short run at the $1 \%$ significance level. Further, the estimate of the lagged $\mathrm{ECM}_{\mathrm{t}-1}$ is statistically significant and has a negative sign at the $1 \%$ significance level. We find that the deviations in the short to the long run are corrected by $34.87 \%$ in each year, which show the low speed of adjustment in the $\operatorname{lnGR}_{t}$. The diagnostic tests show that the estimates are free from misspecification and heteroskedasticity in the short-run model. ${ }^{3}$ The stability of the ARDL parameters is examined by applying the CUSUM and CUSUMsq tests developed by Brown, Durbin and Evans (1975). Figures 1 and Figures 2 show that the plot of the statistics from the CUSUM and CUSUMsq stays within the critical bounds, which indicates the stability of the equation for government revenue.

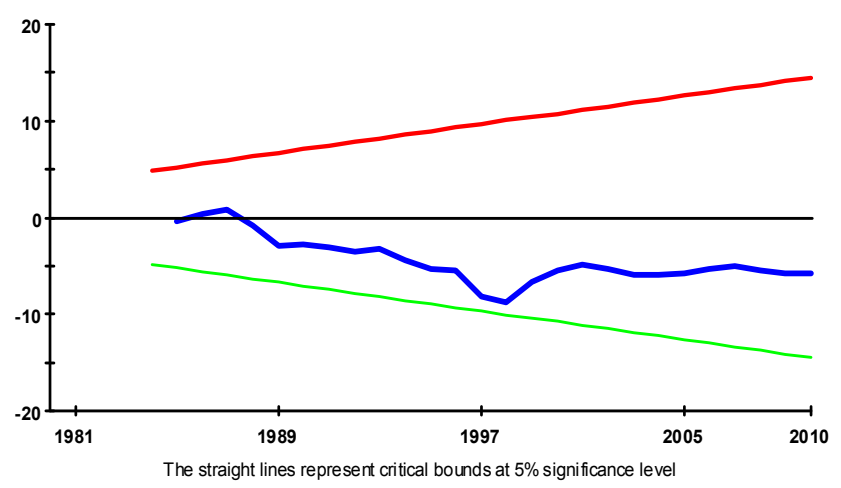

Figure 1. Plot of cumulative sum of recursive residuals (CUSUM)

Plot of Cumulative Sum of Squares of Recursive Residuals

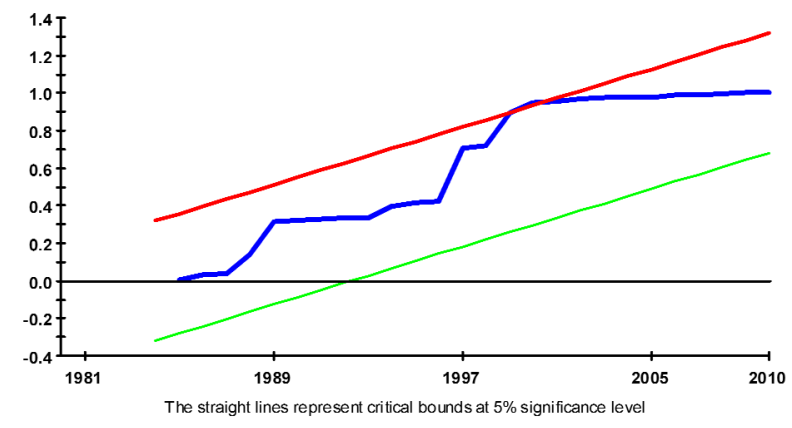

Figure 2. Plot of cumulative sum of squares of recursive residuals (CUSUMsq) 
Table 3. Long-run and short-run analysis

\begin{tabular}{ccc}
\hline & Dependent variable $=\operatorname{lnGR}_{\mathrm{t}}$ & \\
\hline Long run results & Coefficient & T-statistic \\
Variable & -0.4806 & $-3.7611^{*}$ \\
Constant & 1.0383 & $45.9562^{*}$ \\
lnGE & & \\
Short run results & & \\
Variable & Coefficient & T-statistic \\
Constant & 0.0789 & $3.7091^{*}$ \\
$\operatorname{lnGE}_{\mathrm{t}}$ & 0.4440 & $3.7361^{*}$ \\
ECM $_{\mathrm{t}-1}$ & -0.3487 & $-3.3913^{*}$ \\
\hline
\end{tabular}

Note: The $*$ indicates the $1 \%$ significance level.

Table 4 reports the Granger causality results. These results disclose that the estimates of the $\mathrm{ECM}_{\mathrm{t}-1}$ are statistically significant with negative signs at the $5 \%$ significance level. This finding shows that long-run unidirectional causality exists between the $\mathrm{InGE}_{\mathrm{t}}$ and the $\mathrm{InGR}_{\mathrm{t}}$. In addition, short-run bidirectional causality exists between the $\mathrm{InGE}_{\mathrm{t}}$ and the $\mathrm{InGR}_{\mathrm{t}}$. This finding supports the spend-and-tax hypothesis proposed by Peacock \& Wiseman (1961 \& 1979) and Barro (1979). This hypothesis claims that higher expenditures lead to higher taxes later. This support indicates that our study is consistent with many earlier studies such as Anderson et al. (1986) who suggest that governments spend first and then as necessary increase tax revenues to finance spending.

Table 4. VECM granger causality analysis

\begin{tabular}{ccccc}
\hline \multirow{2}{*}{ Dependent variables } & \multicolumn{2}{c}{ Short run } & Long-run & \multirow{2}{*}{ Joint causality } \\
\cline { 2 - 4 } & $\mathrm{InGR}_{\mathrm{t}-1}$ & $\mathrm{InGE}_{\mathrm{t}-1}$ & $\mathrm{ECT}_{\mathrm{t}-1}$ & \\
\hline \multirow{2}{*}{$\mathrm{InGR}_{\mathrm{t}}$} & - & 0.6625 & $-0.379^{* *}$ & $4.5926^{* *}$ \\
& 0.9576 & {$[0.4234]$} & {$[0.0213]$} & {$[0.0200]$} \\
$\mathrm{InGE}_{\mathrm{t}}$ & {$[0.3372]$} & - & -0.014 & 0.6193 \\
& & - & {$[0.9446]$} & {$[0.5464]$} \\
\hline
\end{tabular}

Note: The $*$ and $* *$ show significance at the $1 \%$ and $5 \%$ levels respectively.

\section{Conclusion}

The directional causality between government revenue and spending is necessary information for policy makers when formulating fiscal policy. However, the theoretical and empirical studies do not reach a consensus. This study investigates this causality by using the ARDL bound approach with the Granger causality in a VECM framework. The results show that a long-term link exists between government spending and revenue in the Lao PDR. The unidirectional causality runs from government spending to revenue in the long run, but no causality exists in the short run. These findings support the use of a spend-and-tax policy in Laos. Therefore, the Laos government should spend first and then as necessary increase tax revenues to finance spending.

\section{References}

Anderson, W., Wallace, M. S., \& Warner, J. T. (1986). Government spending and taxation: What causes what? Southern Economic Journal, 52(3), 630-639. http://dx.doi.org/10.2307/1059262

Baghestani, H., \& McNown, R. (1994). Do revenue or expenditure respond to budgetary disequilibria? Southern Economic Journal, 61(2), 311-322. http://dx.doi.org/10.2307/1059979

Barro, R. J. (1979). On the determination of the public debt. Journal of Political Economy, 87(5), 940-971. http://dx.doi.org/10.1086/260807

Brown, R. L., Durbin, J., \& Evans, M. (1975). Techniques for testing the constancy of regression relations over time. Journal of the Royal Statistical Society, 37(2), 149-192. Retrieved from http://www.jstor.org/stable/2984889

Buchanan, J. M., \& Wagner, R. W. (1978). Dialogues concerning fiscal religion. Journal of Monetary Economics, 3(4), 627-636. http://dx.doi.org/10.1016/0304-3932(78)90056-9 
Chang, T., Liu, W. R., \& Caudill, S. B. (2002). Tax-and-spend, spend-and-tax, or fiscal synchronization: New evidence for ten countries. Applied Economics, 34(12), 1553-1561. http://dx.doi.org/10.1080/00036840110103265

Dalena, M., \& Magazzino, C. (2012). Public expenditure and revenue in Italy, 1862-1993. Economic Notes, 41(3), 145-172. http://dx.doi.org/10.1111/j.1468-0300.2012.00243.x

Dickey, A. D., \& Fuller, W. A. (1979). Distribution of the estimators for autoregressive time series with a unit root. Journal of the American Statistical Association, 74(366), 427-431. http://dx.doi.org/10.2307/2286348

Dickey, A. D., \& Fuller, W. A. (1981). Distribution of the estimators for autoregressive time series with a unit root. Econometrica, 49(4), 1057-1072. http://dx.doi.org/10.2307/1912517

Friedman, M. (1978). The limitations of tax limitations. Policy Review, 5, 7-14.

Furstenberg, G. M., Green, R. J., \& Jeong, J. H. (1986). Tax and spend or spend and tax? The Review of Economics and Statistics, 68(2), 179-188. http://dx.doi.org/10.2307/1925496

Gounder, N., \& Narayan, P. K. (2007). An empirical investigation of the relationship between government revenue and expenditure: The case of the Fiji Islands. International Journal of Social Economics, 43(3), 147-158. http://dx.doi.org/10.1108/03068290710726711

Jalil, A. Z. A. (2012). Fiscal decision and fiscal performance: The case of Kelantan and Penang. Procedia Economics and Finance, 1, 193-202. http://dx.doi.org/10.1016/S2212-5671(12)00023-8

Keho, Y. (2010). Budget balance through revenue or spending adjustments? An econometric analysis of the ivorian budgetary process, 1960-2005. Journal of Economics and International Finance, 2(1), 1-11. Retrieved from http://www.academicjournals.org/jeif/pdf/pdf2010/Jan/Keho.pdf

Konukcu-Önal, D., \& Tosun, N. A. (2008). Government revenue-expenditure nexus: Evidence from several transitional economies. Economic Annals, 53(178-179), 145-156. http://dx.doi.org/10.2298/EKA0879145K

Kremers, J. J. M., Ericsson, N. R., \& Dolado, J. J. (1992). The power of cointegration tests. Oxford Bulletin of Economics and Statistics, 54(3), 325-348. http://dx.doi.org/10.1111/j.1468-0084.1992.tb00005.x

Laurenceson, J., \& Chai, J. (2003). Financial reform and economic development in China. Cheltenham, UK: Edward Elgar.

Li, X. (2001). Government revenue, government expenditure and temporal causality: Evidence from China. Applied Economics, 33(4), 485-497. http://dx.doi.org/10.1080/00036840122982

Meltzer, A. H., \& Richard, S. F. (1981). A rational theory of the size of government. Journal of Political Economy, 89(5), 914-927. http://dx.doi.org/10.1086/261013

Moalusi, D. (2004). Causal link between government spending and revenue: A case study of Botswana. Fordham Economics Discussion Paper Series, 7. http://www.fordham.edu/images/Undergraduate/economics/DKMFORD1.pdf

Musgrave, R. A. (1966). Principle of budget determination. In A. H. Cameron \& W. Henderson (Eds.), Public Finance (pp. 914-927). New York: Random House.

Narayan, P. K., \& Narayan, S. (2006). Government revenue and government expenditure nexus: Evidence from developing countries. Applied Economics, 38, 285-291. http://dx.doi.org/10.1080/00036840500369209

Payne, J. E. (2003). A survey of international empirical evidence on the tax-spend debate. Public Finance Review, 31, 302-324. http://dx.doi.org/10.1177/1091142103031003005

Peacock, A. T., \& Wiseman, J. (1961). The growth of public expenditure in the United Kingdom. Princeton University Press. Retrieved from http://www.nber.org/chapters/c2302.pdf

Peacock, A. T., \& Wiseman, J. (1979). Approaches to the analysis of government expenditure growth. Public Finance Review, 7(1), 3-23. http://dx.doi.org/10.1177/109114217900700101

Pesaran, M. H., \& Pesaran, B. (1997). Working with Microfit 4.0: Interactive econometric analysis. Oxford: Oxford University Press.

Pesaran, M. H., \& Shin, Y. (1999). An autoregressive distributed lag modelling approach to cointegration analysis. In Strom, S. (Ed.), Econometrics and Economic Theory in the 20th Century: The Ragnar Frisch Centennial Symposium (pp. 371-413). Cambridge: Cambridge University Press.

Pesaran, M. H., Shin, Y., \& Smith, R. J. (2001). Bounds testing approaches to the analysis of level relations. 
Journal of Applied Econometrics, 16(3), 289-326. http://dx.doi.org/10.1002/jae.616

Phillips, P. C. B., \& Perron, P. (1988). Testing for a unit roots in time series regression. Biometrika, 75(2), $335-$ 346. http://dx.doi.org/10.1093/biomet/75.2.335

Shrestha, M. B., \& Chowdhury, K. (2007). Testing financial liberalization hypothesis with ARDL modeling approach. Applied Financial Economics, 17(8), 1529-1540. http://dx.doi.org/10.1080/09603100601007123

Wolde-Rufael, Y. (2008). The revenue-expenditure nexus: The experience of 13 African countries. African Development Review, 22(2), 273-283. http://dx.doi.org/10.1111/j.1467-8268.2008.00185.x

World Bank. (2012). Lao PDR economic monitor: Tightening demand to maintain macroeconomic balance. World Bank, Vientiane.

\section{Notes}

Note 1. If the calculated F-statistics falls between the lower and upper bounds, it is inclusive. The significance and negative lagged error-correction term has been used for the investigation of cointegration (Kremers et al., 1992).

Note 2. We also set the maximum lag order up to five due to the small sample size. The results are available upon request.

Note 3. The diagnostic tests indicate that serial correlation exists in model. However, the ARDL shows the robustness against the residual autocorrelation. Therefore, it does not cause bias and does not affect the estimation (Laurenceson \& Chai, 2003, p. 30 and Shrestha \& Chowdhury, 2007).

\section{Copyrights}

Copyright for this article is retained by the author(s), with first publication rights granted to the journal.

This is an open-access article distributed under the terms and conditions of the Creative Commons Attribution license (http://creativecommons.org/licenses/by/3.0/). 